\title{
Stability and adaptability of popcorn genotypes in the State of Rio de Janeiro, Brazil
}

\author{
G.F. Pena ${ }^{1}$, A.T. do Amaral Júnior ${ }^{1}$, L.S.A. Gonçalves ${ }^{1}$, L.S. Candido ${ }^{1}$, \\ C. Vittorazzi ${ }^{1}$, R.M. Ribeiro ${ }^{1}$ and S.P. Freitas Júnior ${ }^{2}$ \\ ${ }^{1}$ Universidade Estadual do Norte Fluminense Darcy Ribeiro, \\ Campos dos Goytacazes, RJ, Brasil \\ ${ }^{2}$ Universidade Federal do Ceará, Juazeiro do Norte, CE, Brasil \\ Corresponding author: A.T. do Amaral Júnior \\ E-mail: amaraljr@uenf.br
}

Genet. Mol. Res. 11 (3): 3042-3050 (2012)

Received August 19, 2011

Accepted March 13, 2012

Published August 31, 2012

DOI http://dx.doi.org/10.4238/2012.August.31.1

\begin{abstract}
This study aimed to obtain estimates of stability and adaptability of phase launched materials and materials recommended in the country, for the northern and northwestern regions of Rio de Janeiro State, Brazil, and made a comparative analysis of different methods to evaluate stability and adaptability of grain yield and popping expansion. To this end, 10 genotypes were evaluated (UNB2U-C3, UNB2U-C4, BRS Angela, Viçosa, Beija-Flor, IAC 112, IAC 125, Zélia, Jade, and UFVM2 Barão de Viçosa) in five environments. The Yates and Cochran method revealed that genotypes UFV2M Barão de Viçosa, BRS Angela and UNB2U-C3 were the most stable for grain yield. This method also indicated superiority of genotypes UNB2U-C3, UNB2U-C4, BRS Angela, Viçosa, IAC 125, and Zélia for popping expansion. The Plaisted and Peterson and Wricke methods demonstrated that genotypes Zélia and UNB2U-C4 were the most productive and stable. These methods indicated genotypes UNB2U-C3 and BRS Angela as the most stable for popping expansion. The Kang and Phan ranking system uses methods based on analysis of variance and classified population UNB2U-C4 as the genotype with the highest stability of grain production and confirmed cultivar BRS Angela as the most stable for popping expansion.
\end{abstract}


Genotypes IAC 112 and UNB2U-C4 were the most stable and adapted for grain yield, according to the Lin and Binns method. The $\mathrm{P}_{\mathrm{i}}$ statistics also ranked UNB2U-C3 and UNB2U-C4 as the genotypes with the best predictability and capacity for popping expansion.

Key words: Zea mays; Genetic improvement; Popping expansion; Productivity

\section{INTRODUCTION}

The areas of northern and northwestern Rio de Janeiro are not as agriculturally advanced as other regions in Brazil. These two regions have high rates of rural poverty and, during the last three centuries, have experienced a sequence of economic cycles based on sugarcane, coffee, and cattle raising, which are declining there (Souza et al., 2009). Agricultural diversification with new alternatives for profitable crops is therefore considered a necessary strategy for minimizing socioeconomic problems.

Popcorn is considered an excellent alternative for farmers because it is a highly profitable culture with strong popular acceptance (Aguiar et al., 2008, Mendes de Paula et al., 2010; Moterle et al., 2011, Rangel et al., 2011). Government estimates show that the price obtained for a bag of popcorn $(60 \mathrm{~kg})$ is approximately three times higher than that for a bag of common maize (Agrianual, 2010).

Launching improved materials requires experiments that investigate the performance of cultivars under the environmental conditions of the region. These experiments are essential for the determination of which cultivars will thrive with respect to genotype $\mathrm{x}$ environment (GE) interaction (Prado et al., 2001). GE interaction can be classified as simple when it results only from genetic variability in a genotype. It is classified as complex when there is no correlation between measures of the same genotype in different environments, indicating inconsistency of genotype superiority under environmental variations, which hinders the recommendation of cultivars with wide adaptability (Cruz and Regazzi, 1997).

To minimize the effects of GE interaction and achieve higher performance predictability, the identification of the most stable genotypes and cultivars adapted to the specific conditions of each environment is necessary (Vendruscolo et al., 2001). Several methods have been described to study adaptability and stability-mainly methods based on analysis of variance (Yates and Cochran, 1938; Plaisted and Peterson, 1959; Wricke, 1965; Annicchiarico, 1992), nonparametric analyses (Lin and Binns, 1988; Huehn, 1990; Nascimento et al., 2010), simple linear regression analysis (Theil, 1950; Finlay and Wilkinson, 1963; Eberhart and Russel, 1966; Tai, 1971), bi-segmented regression (Verma et al., 1978; Silva and Barreto, 1985; Cruz et al., 1989; Storck and Vencovsky, 1994), quadratic regression (Brasil and Chaves, 1994), and multivariate analysis, such as the additive main effects and multiplicative interaction analysis (Zobel et al., 1988) and principal components analysis (Crossa, 1990). Also applicable is the ranking method proposed by Kang and Phan (1991), which uses the weights between the parameters of adaptability and phenotype stability of correlated methods and the average of the estimates of the trait analyzed to classify genotypes.

According to Cruz et al. (2004), the selection of the method to be used by breeders depends on the number of environments available, the type of information required, and the 
needed experimental accuracy. In addition, some methods can be combined because they are considered alternative or complementary. Above all, the methods should have a high level of agreement in the parameters of stability and adaptability (Duarte and Zimmermann, 1995; Scapim et al., 2010).

This study aimed to (1) obtain estimates of stability and adaptability of phase-launched materials for northern and northwestern Rio de Janeiro as well as for materials recommended in the country, and (2) carry out a comparative analysis of methods for assessing stability and adaptability of grain yield (GY) and popping expansion (PE).

\section{MATERIAL AND METHODS}

The experiments were carried out in 2007/2008 (Colégio Estadual Agrícola Antônio Sarlo and Estação Experimental da PESAGRO-RIO, Campos dos Goytacazes; and PESAGRO-RIO, Itaocara) and 2009/2010 (PESAGRO-RIO, Campos dos Goytacazes; Colégio Estadual Agrícola de Cambuci, Cambuci; and PESAGRO-RIO, Itaocara) in five environments representing northern and northwestern Rio de Janeiro. The following genotypes of popcorn were used: UNB2U-C3, UNB2U-C4, BRS Angela, Viçosa, Beija-Flor, IAC 112, IAC 125, Zélia, Jade, and UFVM2 Barão de Viçosa. A randomized block experimental design was used, with three replications. The plots had two 12-m rows, with spacing of $0.9 \mathrm{~m}$ between rows and $0.2 \mathrm{~m}$ between plants, totaling 120 plants per plot. Three seeds were used per hole at a depth of 0.05 meters, and thinning was carried out 21 days after emergence. Topdressing and other treatments recommended for the culture were performed (Sawazaki, 2001).

Two main traits of the popcorn cultures were evaluated: GY and PE. GY was determined based on the average of the plot by the weighing of grains after their removal from cob and expressed in kilograms per hectare. Grain PE was determined in a laboratory by microwaving $30 \mathrm{~g}$ of seeds in a special plastic pot at $1000 \mathrm{~W}$ for 2 min and $40 \mathrm{~s}$, with 2 replications per treatment. The expanded volume was measured in a graduated cylinder, and PE was calculated from the ratio between the expanded final volume (milliliters) and the initial weight of the grains $(30 \mathrm{~g})$.

Individual analyses of variance were conducted, followed by a joint analysis of variance. In the joint analysis, the homogeneity of the residual variances of the experiments (MSRs) was evaluated first and verified by the ratio between the highest and lowest residual mean square of the tests (GY: 5.39 and PE: 3.69). According to Pimentel-Gomes (1990), the variances are considered homogeneous when the ratio between the highest and lowest MSR is less than 7.0.

The following methods were used to estimate phenotype stability and adaptability: Yates and Cochran (1938), Plaisted and Peterson (1959), Wricke (1965), Lin and Binns (1988), and Kang and Phan (1991). In this work, Kang and Phan (1991) commented on the methods of Yates and Cochran (1938), Plaisted and Peterson (1959), and Wricke (1965).

\section{RESULTS AND DISCUSSION}

In the joint analysis of variance, significant differences were observed by applying the $\mathrm{F}$ test for the characteristics GY and PE considering the sources of genotype variation 
and environment, which indicates the existence of genetic variability among genotypes and environments (Table 1). GE was also significantly different for both traits, indicating that the genotype response differed in the five environments evaluated. This result reveals the need for more detailed study aimed at identifying materials with higher phenotype stability. According to Cruz et al. (2004), aside from affecting the process of cultivar recommendation, GE interaction makes the job of breeders more precise, forcing them to use alternative methods to identify genotypes with high genetic potential.

Table 1. Mean squares, averages and coefficients of variation of two experimental characteristics evaluated in
five environments and in ten popcorn genotypes.
\begin{tabular}{lccr}
\hline SV & d.f. & \multicolumn{3}{c}{ Mean squares $^{1 / 1}$} \\
\cline { 2 - 4 } & & PE & GY \\
\hline Block/environment & 10 & 3.55 & 729306.90 \\
Genotype (G) & 9 & $252.71^{* *}$ & $1392072.60^{* *}$ \\
Environment (E) & 4 & $161.83^{* *}$ & $5442885.13^{* *}$ \\
G x E & 36 & $25.64^{* *}$ & $589171.91^{* *}$ \\
Residue & 90 & 4.83 & 256577.77 \\
Average & - & 27.53 & 1985.12 \\
CVe (\%) & - & 7.98 & 25.51 \\
MSR $^{+} / M_{S R}$ & - & 3.69 & 5.39 \\
\hline
\end{tabular}

${ }^{1 / \mathrm{PE}}=$ popping expansion and $\mathrm{GY}=$ grain yield. $* *=$ Significant at $1 \%$ probability.

GY ranged from $1340.72 \mathrm{~kg} / \mathrm{ha}(2009 / 2010$, PESAGRO-RIO, Itaocara) to 2390.82 $\mathrm{kg} / \mathrm{ha}(2009 / 2010$, Cambuci), with an average of $1985.12 \mathrm{~kg} / \mathrm{ha}$ among the environments. The highest productivity and the highest average productivity in all of the environments were achieved by the hybrid IAC 112 (3533.92 and $2474.94 \mathrm{~kg} / \mathrm{ha}$, respectively). The population UNB2U-C4, from the Universidade Estadual do Norte Fluminense Darcy Ribeiro recurrent selection program, achieved the second highest productivity average in all of the environments, with $2364.54 \mathrm{~kg} / \mathrm{ha}$. PE ranged from $25.76 \mathrm{~mL} / \mathrm{g}(2007 / 2008$, PESAGRORIO, Campos dos Goytacazes) to $31.49 \mathrm{~mL} / \mathrm{g}$ (2009/2010, Cambuci), with an average of $27.54 \mathrm{~mL} / \mathrm{g}$ among all environments. The highest PE and the highest average PE in all of the environments were achieved by the hybrid IAC 125 (37.22 and $32.89 \mathrm{~mL} / \mathrm{g}$, respectively). UNB2U-C4 achieved the fifth highest average $(28.80 \mathrm{~mL} / \mathrm{g})$, following the genotypes BRS Angela, IAC 112, and Zélia, with 32.61, 30.64, and $29.60 \mathrm{~mL} / \mathrm{g}$, respectively.

Table 2 presents the parameter estimates of phenotype stability and adaptability for GY and PE, respectively. According to the method of Yates and Cochran (1938), the genotypes that presented the mean square lowest estimates (stability "a" level) for the characteristic GY were the varieties UFVM2 Barão de Viçosa and BRS Angela and the experimental population UNB2U-C3, which are, therefore, considered the most stable in all environments. With respect to PE, the genotypes UNB2U-C3, UNB2U-C4, BRS Angela, Viçosa, IAC 125, and Zélia contained the lowest mean square values. Therefore, they are classified as the most stable.

Applying the methodologies developed by Plaisted and Peterson (1959) and Wricke (1965) demonstrated that the genotypes UNB2U-C4 and Zélia were the most stable for GY, whereas for PE, the most stable were UNB2U-C3 and BRS Angela, because they expressed the highest phenotype stability-i.e., they achieved the lowest values of $\hat{\theta}_{i}$ and $\hat{\omega}_{i}$. 
Table 2. Estimates of the parameters of stability and adaptability [YC: Yates and Cochran (1938), PP: Plaisted and Peterson (1959), W: Wricke (1965) and LB: Lin and Binns (1988)] for average yield of grains and popping expansion, in the evaluation of ten genotypes of popcorn.

\begin{tabular}{|c|c|c|c|c|c|c|c|c|}
\hline \multicolumn{9}{|l|}{ Grain yield } \\
\hline \multirow[t]{2}{*}{ Genotypes } & \multirow[t]{2}{*}{ Average (kg/ha) } & \multicolumn{2}{|l|}{$\mathrm{YC}$} & \multirow{2}{*}{$\frac{\mathrm{PP}}{\hat{\theta}_{\mathbf{i}}(\%)}$} & \multirow{2}{*}{$\frac{\mathrm{W}}{\widehat{\omega_{\mathrm{i}}(\%)}}$} & \multicolumn{3}{|c|}{ LB } \\
\hline & & $\mathrm{MS}^{2 /}$ & $\mathrm{LS}^{2 /}$ & & & $P_{i} / 10000$ & $\mathrm{P}_{\mathrm{i}}(+) / 10000$ & $\mathrm{P}_{\mathrm{i}}(-) / 10000$ \\
\hline 1 & 1920.76 & 438486.08 & $\mathrm{a}$ & 5.07 & 4.43 & 39.88 & 48.62 & 26.78 \\
\hline 2 & 2364.53 & 759357.41 & $\mathrm{~b}$ & 2.22 & 1.21 & 15.38 & 12.06 & 15.88 \\
\hline 3 & 1875.68 & 144823.01 & $\mathrm{a}$ & 9.75 & 9.72 & 50.48 & 73.55 & 50.24 \\
\hline 4 & 2132.65 & 978153.92 & $\mathrm{~b}$ & 6.52 & 6.08 & 27.62 & 27.33 & 26.78 \\
\hline 5 & 1796.85 & 2738796.3 & $\mathrm{~b}$ & 20.20 & 21.51 & 71.96 & 40.92 & 28.06 \\
\hline 6 & 2474.94 & 1382675.21 & $\mathrm{~b}$ & 17.89 & 18.91 & 8.72 & 5.93 & 12.90 \\
\hline 7 & 1504.01 & 2466660.91 & $\mathrm{~b}$ & 25.67 & 27.69 & 117.21 & 106.18 & 133.76 \\
\hline 8 & 2022.22 & 1049174.68 & $\mathrm{~b}$ & 2.84 & 1.92 & 34.44 & 23.90 & 26.20 \\
\hline 9 & 2127.77 & 657696.70 & $\mathrm{~b}$ & 4.43 & 3.72 & 23.04 & 20.94 & 20.37 \\
\hline 10 & 1631.79 & 129608.06 & $\mathrm{a}$ & 5.37 & 4.78 & 73.63 & 92.26 & 118.52 \\
\hline \multicolumn{9}{|c|}{ Popping expansion } \\
\hline \multirow[t]{2}{*}{ Genotypes } & Average (kg/ha) & \multicolumn{2}{|l|}{$\mathrm{YC}$} & PP & W & \multicolumn{3}{|c|}{ LB } \\
\hline & & $\mathrm{MS}^{2 /}$ & $\mathrm{LS}^{2 /}$ & $\hat{\theta}_{\mathrm{i}}(\%)$ & $\hat{\omega_{\mathrm{i}}}(\%)$ & $P_{i} / 10000$ & $\mathrm{P}_{\mathrm{i}}(+) / 10000$ & $\mathrm{P}_{\mathrm{i}}(-) / 10000$ \\
\hline 1 & 26.21 & 9.08 & $\mathrm{a}$ & 5.22 & 2.25 & 29.28 & 33.34 & 64.71 \\
\hline 2 & 28.80 & 4.81 & $\mathrm{a}$ & 9.79 & 9.67 & 14.12 & 32.51 & 37.28 \\
\hline 3 & 32.61 & 6.21 & $\mathrm{a}$ & 5.47 & 2.65 & 1.06 & 4.17 & 9.52 \\
\hline 4 & 21.16 & 8.61 & $\mathrm{a}$ & 6.60 & 4.49 & 80.42 & 112.50 & 72.68 \\
\hline 5 & 22.24 & 38.98 & $\mathrm{~b}$ & 5.50 & 2.70 & 66.54 & 42.01 & 72.40 \\
\hline 6 & 30.64 & 89.36 & $\mathrm{~b}$ & 14.66 & 17.56 & 10.15 & 0 & 0.28 \\
\hline 7 & 32.89 & 21.16 & a & 5.78 & 3.15 & 0.82 & 0 & 1.03 \\
\hline 8 & 29.60 & 19.90 & a & 12.80 & 14.54 & 12.63 & 18.02 & 28.26 \\
\hline 9 & 26.99 & 75.66 & b & 15.64 & 19.15 & 31.34 & 7.56 & 11.28 \\
\hline 10 & 24.22 & 118.83 & $\mathrm{~b}$ & 18.51 & 23.81 & 53.51 & 33.34 & 12.68 \\
\hline
\end{tabular}

${ }_{1 / 1}=$ UNB2U-C3; 2 = UNB2U-C4; 3 BRS Angela; 4 = Viçosa; 5 = Beija-Flor; 6 = IAC 112; 7 = IAC 125; 8 = Zélia; $9=$ Jade and $10=$ UFVM2 Barão de Viçosa. ${ }^{2 /} \mathrm{MS}=$ mean square; $\mathrm{LS}=$ levels of stability.

According to the $\mathrm{P}_{\mathrm{i}}$ statistics of Lin and Binns (1988), the hybrid IAC 112 and the population UNB2U-C4 were the most stable genotypes for GY. According to the decomposition rate of $\mathrm{Pi}$, to quantify the response of genotypes in different environments, we observed that IAC 112 was the most stable for GY, providing good response to favorable $\left(\mathrm{P}_{\mathrm{if}}\right)$ environments in addition to being adapted to unfavorable $\left(\mathrm{P}_{\text {id }}\right)$ environments (lower $\mathrm{P}_{\text {if }}$ and $\mathrm{P}_{\text {id }}$ estimates). For $\mathrm{PE}$, the genotype IAC 125 expressed the lowest superiority index $\left(\mathrm{P}_{\mathrm{i}}=0.82\right)$, followed by the genotypes BRS Angela and IAC 112, with 1.06 and 10.15, respectively. In the decomposition of the index, it seems that 125 IAC also displayed better results in both types of environments (favorable and unfavorable) for popping expansion, occupying the second position in both. The population UNB2U-C4 was classified according to the methodology of Lin and Binns (1988) as the third most responsive for PE in unfavorable environments, which reflects a good response in this genotype under those conditions.

Analyzing GY according to the ranking system of Kang and Phan (1991) with the sum of 2 rankings (GY and stability parameter) for 3 weights (Yates and Cochran, Plaisted and Peterson, and Wricke), the population UNB2U-C4 demonstrated the lowest grade, thus being classified as providing the highest concomitant average yield and behavior stability (Table 3 ). In the results for PE, the cultivar BRS Angela received the lowest score in the ranking systems and was considered to provide the best PE when simultaneously compared with behavior sta- 
bility. Considering PE with the stability parameter of the method of Yates and Cochran (1938) in the ranking we performed, the experimental population UNB2U-C4 was the second most stable and expanding. For the other 2 weights, this population was reclassified to the fourth position demonstrating the same grade as that of the triple hybrids IAC 112 and Zélia (see Table $3)$. Therefore, promising results are expected for the achievement of new cycles of recurrent selection with UNB2U.

Table 3. Genotype ranking by the methodology of Kang and Phan (1991), applied to the methods of Yates and Cochran (1938) (YC), Plaisted and Peterson (1959) (PP) and Wricke (1965) (W) in the evaluation of ten genotypes of popcorn for grain yield and popping expansion.

\begin{tabular}{|c|c|c|c|c|c|c|c|c|}
\hline \multicolumn{9}{|l|}{ Grain yield } \\
\hline \multirow[t]{2}{*}{ Genotypes $^{1 /}$} & \multirow[t]{2}{*}{ Grain yield } & \multirow[t]{2}{*}{ Rank for grain yield } & \multicolumn{2}{|r|}{$\mathrm{YC}$} & \multicolumn{2}{|c|}{$\mathrm{PP}$} & \multicolumn{2}{|c|}{$\mathrm{W}$} \\
\hline & & & Rank & Rank total & Rank & Rank total & Rank & Rank total \\
\hline 1 & 1920.76 & 6 & 3 & 9 & 4 & 10 & 4 & 10 \\
\hline 2 & 2364.53 & 2 & 5 & 7 & 1 & 3 & 1 & 3 \\
\hline 3 & 1875.68 & 7 & 2 & 9 & 7 & 14 & 7 & 14 \\
\hline 4 & 2132.65 & 3 & 6 & 9 & 6 & 9 & 6 & 9 \\
\hline 5 & 1796.85 & 8 & 10 & 18 & 9 & 17 & 9 & 17 \\
\hline 6 & 2474.94 & 1 & 8 & 9 & 8 & 9 & 8 & 16 \\
\hline 7 & 1504.01 & 10 & 9 & 19 & 10 & 20 & 10 & 20 \\
\hline 8 & 2022.22 & 5 & 7 & 12 & 2 & 7 & 2 & 7 \\
\hline 9 & 2127.77 & 4 & 4 & 8 & 3 & 7 & 3 & 7 \\
\hline 10 & 1631.79 & 9 & 1 & 10 & 5 & 14 & 5 & 14 \\
\hline \multicolumn{9}{|c|}{ Popping expansion } \\
\hline \multirow[t]{2}{*}{ Genotypes $^{1 /}$} & Popping expansion & Rank for popping & \multicolumn{2}{|r|}{$\mathrm{YC}$} & \multicolumn{2}{|c|}{ PP } & \multicolumn{2}{|c|}{ W } \\
\hline & & & Rank & Rank total & Rank & Rank total & Rank & Rank total \\
\hline 1 & 26.21 & 7 & 4 & 11 & 1 & 8 & 1 & 8 \\
\hline 2 & 28.80 & 5 & 1 & 6 & 6 & 11 & 6 & 11 \\
\hline 3 & 32.61 & 2 & 2 & 4 & 2 & 4 & 2 & 4 \\
\hline 4 & 21.16 & 10 & 3 & 13 & 5 & 15 & 5 & 15 \\
\hline 5 & 22.24 & 9 & 7 & 16 & 3 & 12 & 3 & 12 \\
\hline 6 & 30.64 & 3 & 9 & 12 & 8 & 11 & 8 & 11 \\
\hline 7 & 32.89 & 1 & 6 & 7 & 4 & 5 & 4 & 5 \\
\hline 8 & 29.60 & 4 & 5 & 9 & 7 & 11 & 7 & 11 \\
\hline 9 & 26.99 & 6 & 8 & 14 & 9 & 15 & 9 & 15 \\
\hline 10 & 24.22 & 8 & 10 & 18 & 10 & 18 & 10 & 18 \\
\hline
\end{tabular}

${ }_{1}^{1 / 1}=$ UNB2U-C3; 2 = UNB2U-C4; 3 = BRS Angela; 4 = Viçosa; 5 = Beija-Flor; $6=$ IAC 112; 7 = IAC 125; $8=$ Zélia; 9 = Jade and $10=$ UFVM2 Barão de Viçosa.

Tables 4 and 5, which contain the associations between the methods for the characteristics GY and PE, show that 44.44 and $30.55 \%$ of the algorithms, respectively, revealed statistical significance, indicating that these methods partly agree. The methods of Plaisted and Peterson (1959) and Wricke (1965) obtained a correlation 1.00 for both GY and PE. The perfect agreement of these two methods of stability in the estimates of the parameters reveals that the indication of cultivars is the same, regardless of the method, and that using both methods is unnecessary. This result agrees with those obtained by Silva and Duarte (2006), Cargnelluti Filho et al. (2009), and Vilela et al. (2011).

For PE, the method of Yates and Cochran (1938), Plaisted and Peterson (1959), and Wricke (1965) correlated positively and highly significantly with the parameters of Lin and Binns (1988) for both $\mathrm{P}_{\text {if }}$ and $\mathrm{P}_{\mathrm{iu}}$. Based on these significant agreements among the parameters, 
we can infer that the most stable genotypes, according to the methodologies of Yates and Cochran (1938) and Plaisted and Peterson (1959) or Wricke (1965), are likely adaptable and stable for both favorable and unfavorable environments for PE. A high positive significance $(\mathrm{P}<0.01)$ also occurred among $\mathrm{P}_{\mathrm{ig}}, \mathrm{P}_{\mathrm{if}}$, and $\mathrm{P}_{\mathrm{iu}}$ of Lin and Binns (1988) for GY and PE, possibly owing to the relative agreement in genotype rankings in both favorable and unfavorable environments.

\begin{tabular}{|c|c|c|c|c|c|c|c|c|}
\hline Methodologies $^{1 /}$ & PP & $\mathrm{W}$ & $\begin{array}{l}\text { YC weighted by } \\
\text { Kang and Phan }\end{array}$ & $\begin{array}{l}\text { PP weighted by } \\
\text { Kang and Phan }\end{array}$ & $\begin{array}{l}\text { W weighted by } \\
\text { Kang and Phan }\end{array}$ & $\mathrm{LB}\left(\mathrm{P}_{\mathrm{Ig}}\right)$ & $\mathrm{LB}\left(\mathrm{P}_{\mathrm{if}}\right)$ & $\mathrm{LB}\left(\mathrm{P}_{\mathrm{iu}}\right)$ \\
\hline YC & $0.4788^{\mathrm{ns}}$ & $0.4788^{\text {ns }}$ & $0.4877^{\text {ns }}$ & $0.1651^{\text {ns }}$ & $0.3963^{\text {ns }}$ & $-0.030^{\text {ns }}$ & $-0.224^{\text {ns }}$ & $0.14025^{\mathrm{n}}$ \\
\hline PP & & $1.00^{* *}$ & $0.6128^{\text {ns }}$ & $0.8440^{* *}$ & $0.9512 * *$ & $0.4909^{\text {ns }}$ & $0.4545^{\mathrm{ns}}$ & $0.4878^{\mathrm{ns}}$ \\
\hline $\mathrm{W}$ & & & $0.6128^{\text {ns }}$ & $0.8440^{* *}$ & $0.9512^{* *}$ & $0.4909^{\text {ns }}$ & $0.4545^{\mathrm{ns}}$ & $0.4878^{\mathrm{ns}}$ \\
\hline YC weighted by Kang and Phan & & & & $0.7352^{*}$ & $0.7014^{*}$ & $0.7691^{* *}$ & $0.6128^{\text {ns }}$ & $0.8524 * *$ \\
\hline PP weighted by Kang and Phan & & & & & $0.9046 * *$ & $0.8563^{* *}$ & $0.8257^{* *}$ & $0.7784 * *$ \\
\hline W weighted by Kang and Phan & & & & & & $0.6036^{\mathrm{ns}}$ & $0.5427^{\mathrm{ns}}$ & $0.5552^{\mathrm{ns}}$ \\
\hline & & & & & & & $0.9515^{* *}$ & $0.9512^{* *}$ \\
\hline LB $\left(P_{i, j}\right)$ & & & & & & & & $0.8536^{* *}$ \\
\hline
\end{tabular}

Table 5. Estimates of Spearman correlations among methods of stability and adaptability for the analysis of the efficiency of different algorithms to identify genotypes of popcorn evaluated for the popping expansion.

\begin{tabular}{|c|c|c|c|c|c|c|c|c|}
\hline Methodologies $^{1 /}$ & PP & W & $\begin{array}{l}\text { YC weighted by } \\
\text { Kang and Phan }\end{array}$ & $\begin{array}{l}\text { PP weighted by } \\
\text { Kang and Phan }\end{array}$ & $\begin{array}{l}\text { W weighted by } \\
\text { Kang and Phan }\end{array}$ & $\mathrm{LB}\left(\mathrm{P}_{\mathrm{Ig}}\right)$ & $\operatorname{LB}\left(\mathrm{P}_{\mathrm{if}}\right)$ & $\operatorname{LB}\left(\mathrm{P}_{\mathrm{iu}}\right)$ \\
\hline YC & $0.6121^{\mathrm{ns}}$ & $0.6121^{\mathrm{ns}}$ & $0.3564^{\mathrm{ns}}$ & $0.2691^{\mathrm{ns}}$ & $0.4390^{\mathrm{ns}}$ & $0.1515^{\mathrm{ns}}$ & $0.8024 * *$ & $0.7818 * *$ \\
\hline PP & & $1.00 * *$ & $-0.1688^{\mathrm{ns}}$ & $-0.428^{\mathrm{ns}}$ & $-0.274^{\mathrm{ns}}$ & $0.1636^{\mathrm{ns}}$ & $0.7538^{*}$ & $0.7818 * *$ \\
\hline W & & & $-0.1688^{\mathrm{ns}}$ & $-0.428^{\mathrm{ns}}$ & $-0.274^{\mathrm{ns}}$ & $0.1636^{\mathrm{ns}}$ & $0.7538 *$ & $0.7818 * *$ \\
\hline YC weighted by Kang and Phan & & & & $0.7352 *$ & $0.7014^{*}$ & $-0.125^{\mathrm{ns}}$ & $0.3920^{\text {ns }}$ & $0.3689^{\text {ns }}$ \\
\hline PP weighted by Kang and Phan & & & & & $0.9046 * *$ & $-0.116^{\mathrm{ns}}$ & $0.0981^{\mathrm{ns}}$ & $0.0672^{\text {ns }}$ \\
\hline W weighted by Kang and Phan & & & & & & $-0.244^{\mathrm{ns}}$ & $0.1529^{\text {ns }}$ & $0.1280^{\mathrm{ns}}$ \\
\hline $\mathrm{LB}\left(\mathrm{P}_{\mathrm{Ig}}\right)$ & & & & & & & $0.0608^{\mathrm{ns}}$ & $0.0545^{\mathrm{ns}}$ \\
\hline $\mathrm{LB}\left(\mathrm{P}_{\mathrm{if}}\right)$ & & & & & & & & $0.9969 * *$ \\
\hline
\end{tabular}

Using the method of Kang and Phan (1991) for GY, the method of Yates and Cochran (1938) started to correlate positively $(\mathrm{P}<0.01)$ with the methods of Plaisted and Peterson (1959) and Wricke (1965), both also weighted by the same ranking methodology. Furthermore, on the effect of weighting in the method of Yates and Cochran (1938) for GY, a markedly increased correlation occurred between the stability parameter and the parameters of Lin and Binns (1988), and GY became positively correlated at $1 \%$ probability with $\mathrm{P}_{\mathrm{ig}}(\mathrm{r}=0.76)$ and $\mathrm{P}_{\text {iu }}(\mathrm{r}=0.85)$. The weighting proposed by Kang and Phan (1991) became the parameter of Plaisted and Peterson (1959), highly correlated with all parameters of Linn and Binns (1988): $\mathrm{P}_{\text {ig }}(0.85), \mathrm{P}_{\text {if }}(0.82)$, and $\mathrm{P}_{\text {iu }}(0.77)$ for GY. Similar results were obtained by Vilela et al. (2011), which highlights the usefulness of the method of Kang and Phan (1991) for generating more 
robust data, specifically with respect to the estimates of the parameters of the methods of Yates and Cochran (1938) and Plaisted and Peterson (1959).

The analysis of the usefulness of the method of Kang and Phan (1991) for the characteristic PE revealed results that differed from those found for GY. The weights of Kang and Phan (1991) for PE, in the method of Yates and Cochran (1938), became highly significant only for the methods of Plaisted and Peterson (1959) and Wricke (1965), also weighted by the same ranking system. It resulted in a sharp decrease in the correlations among all the parameters of the methods of Lin and Binns (1988), however. The correlations with the method of Plaisted and Peterson (1959) were also sharply reduced among the other parameters of the various methods after weighting by the method of Kang and Phan (1991). It was also observed with the parameters of Wricke (1965), which did not correlate with any other parameter of stability (see Table 5) after weighting by the method of Kang and Phan (1991). For PE, the use of the method of Kang and Phan (1991) did not reveal positive attributions for the data of this study.

\section{REFERENCES}

Agrianual (Anuário da Agricultura Brasileira) (2010). FNP Consultoria \& Comércio. M\&S Mendes \& Scotini. Editora Argos, 521.

Aguiar CG, Schuster I, Amaral AT Jr, Scapim CA, et al. (2008). Heterotic groups in tropical maize germplasm by test crosses and simple sequence repeat markers. Genet. Mol. Res. 7: 1233-1244.

Annicchiarico P (1992). Cultivar adaptation and recommendation from alfalfa trials in northern italy. J. Genet. Breed. 46: 269-278.

Brasil EM and Chaves LJ (1994). Utilizacion de un Modelo Cuadratico para el Estudio de la Respuesta de Cultivares a la Variacion Ambiental. In: Anais do $11^{\circ}$ Congresso Latinoamericano de Genetica.

Crossa J (1990). Statistical analysis of multilocations trials. Adv. Agron. 44: 55-85.

Cruz CD and Regazzi AJ (1997). Modelos Biométricos Aplicados ao Melhoramento Genético. Vol. 2. Editora UFV, Viçosa.

Cruz CD, Torres RAA and Vencovsky R (1989). An alternative approach to the stability analysis proposed by Silva and Barreto. Rev. Bras. Gen. 12: 567-580.

Cruz CD, Regazzi AJ and Carneiro PCS (2004). Modelos Biométricos Aplicados ao Melhoramento Genético. Vol. 1. Editora UFV, Viçosa.

Duarte JB and Zimmermann MJO (1995). Correlation among yield stability parameters in common bean. Crop Sci. 35: 905-912.

Eberhart SA and Russel WA (1996). Stability parameters for comparing varieties. Crop Sci. 6: 36-40.

Filho AC, Storck L, Riboldi J and Guadagnin JP (2009). Associação entre métodos de adaptabilidade e estabilidade em milho. Cienc. Rural 39: 340-347.

Finlay KW and Wilkinson GN (1963). The analysis of adaptation in a plant breeding programmme. Aust. J. Agr. Res. 14: 742-754.

Huehn M (1990). Nonparametric measures of phenotipic stability. Part 1: theory. Euphytica 47: 189-194.

Kang MS and Phan HN (1991). Simultaneous selection for high yielding and stable crop genotypes. Agron. J. 83: 161-165.

Lin CS and Binns MR (1988). A superiority measure of cultivar performance for cultivar x location data. Can. J. Plant Sci. 68: 193-198.

Mendes de Paula TO, Amaral Júnior AT, Gonçalves LSA, Scapim CA, et al. (2010). Pi statistics underlying the evaluation of stability, adaptability and relation between the genetic structure and homeostasis in popcorn. Acta Sci. Agron. 32: 269-277.

Moterle LM, Lucca e Braccini A, Scapim CA, Pinto RJB, et al. (2011). Combining ability of popcorn lines for seed quality and agronomic traits. Euphytica DOI: 10.1007/s10681-011-0458-2.

Nascimento M, Ferreira A, Ferrão RG, Campana ACM, et al. (2010). Adaptabilidade e estabilidade via regressão não paramétrica em genótipos de café. Pesq. Agropec. Bras. 45: 41-48.

Pimentel Gomes F (1990). Curso de Estatística Experimental. Nobel Company, São Paulo.

Plaisted RL and Peterson LC (1959). A technique for evaluation the ability of selection the yield consistently in different 
locations or seasons. Am. Potato J. 36: 381-385.

Prado EE, Hiromoto DM, Godinho VPC, Utumi MM, et al. (2001). Adaptabilidade e estabilidade de cultivares de soja em cinco épocas de plantio no cerrado de Rondônia. Pesq. Agropec. Bras. 36: 625-635.

Rangel RM, Amaral Júnior AT, Gonçalves LSA, Freitas Júnior SP, et al. (2011). Análise biométrica de ganhos por seleção em população de milho pipoca de quinto ciclo de seleção recorrente. Rev. Cienc. Agron. 42: 473-481.

Sawazaki E (2001). A cultura do milho pipoca no Brasil. O Agronômico 53: 11-13.

Scapim A, Pacheco CAP, Amaral Júnior AT, Vieira RA, et al. (2010). Correlations between the stability and adaptability statistics of popcorn cultivars. Euphytica 174: 209-218.

Silva JGC and Barreto JN (1985). Aplicação da Regressão Linear Segmentada em Estudos da Interação Genótipo por Ambiente. In: Anais do Simpósio de Estatística Aplicada à Experimentação Agronômica.

Silva WCJ and Duarte JB (2006). Métodos estatísticos para estudo de adaptabilidade e estabilidade fenotípica em soja. Pesq. Agropec. Bras. 41: 23-30.

Souza PM, Ponciano NJ, Mata HTC, Brito MN, et al. (2009). Padrão de desenvolvimento tecnológico dos municípios das regiões norte e noroeste do Rio de Janeiro. Rev. Econ. Sociol. Rural 47: 945-969.

Storck L and Vencovsky R (1994). Stability analysis based on a bi-segmented discontinuous model with measurement errors in the variables. Rev. Bras. Gen. 17: 75-81.

Tai GCC (1971). Genotypic stability analysis and its application to potato regional trials. Crop Sci. 11: 184-190.

Theil H (1950). A rank-invariant method of linear and polynomial regression analysis. Indagationes Mathematicae 12: 85-91.

Vendruscolo ECG, Scapim CA, Pacheco CAP, Oliveira VR, et al. (2001). Adaptabilidade e estabilidade de cultivares de milho-pipoca na região centro-sul do Brasil. Pesq. Agropec. Bras. 36: 123-130.

Verma MM, Chahal GS and Murty BR (1978). Limitations of conventional regression analysis a proposed modification. Theor. Appl. Genet. 53: 89-91.

Vilela FO, Amaral Júnior AT, Gonçalves LSA, Barbé TC, et al. (2011). Stability of $\mathrm{F}_{7: 8}$ snap bean progenies in the Northern and Northwestern regions of Rio de Janeiro State. Hort. Bras. 29: 84-90.

Wricke G (1965). Zur berechnung der ökovalenz bei sommerweizen und hafer. Pflanzenzuchtung 52: 127-138. 